\title{
Bioerosive processes affecting a population of brachiopods (Upper Pliocene, Apulia)
}

\author{
EMMA TADDEI RUGGIERO
}

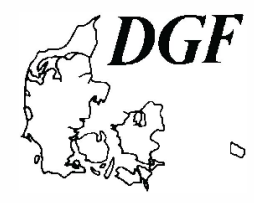

Taddei Ruggiero, E.: Bioerosive processes affecting a population of brachiopods (Upper Pliocene, Apulia). Bulletin of the Geological Society of Denmark, Vol. 45, pp. 169-172. Copenhagen, 1999-01-30. https://doi.org/10.37570/bgsd-1998-45-23

The most important forms of bioerosion affecting the brachiopod Terebratula calabra in life may be classified as surface etchings, borings, and shell breakage. Ichnogenera observed are Oichnus, Podichnus, Entobia, Centrichnus and Ren-ichnus.

Key words: Bioerosion, brachiopods, palaeoecology, Upper Pliocene.

E. Taddei Ruggiero, Dipartimento di Scienze della Terra, Università di Napoli "Federico II", Largo S. Marcellino 10, 80138 Napoli, Italy; 15 July, 1998.

Damage produced by endolithic organisms on live brachiopods has been studied in an Upper Pliocene population of Terebratula calabra Seguenza, from Poggiofranco, near Cerignola (Foggia, Italy). The material consists of ca. 600 specimens.

The most important forms of bioerosion affecting the shells of brachiopods found in this study are of three kinds: shell breakage, borings and surface etchings.

\section{Shell breakage}

Evidence of breakage is observable as trace fossils positioned along the growth lines. Trauma took place on what was at that moment the edge of the shell. Fractures can be long and irregular (Fig. 1A) or may affect only a small portion of the shell (Fig. 1B). Traces similar to these were attributed by some authors to predatory activities either by decapod crustaceans or by carnivorous gastropods.

\section{Borings}

Oichnus ispp. Bromley, 1981 (Fig. 1C-H)

Three types of trace fossils have been found that are identifiable with this ichnogenus:

1. Subcircular boreholes (15 specimens, 1.5-2.5 $\mathrm{mm}$ in diameter), 10 of them penetrating right through the shell. These are interpreted as the work of carnivorous gastropods (Fig. 1C-D);

2. Subcircular holes (2 specimens, $1-1.5 \mathrm{~mm}$ in diameter) with a typical side gutter (Fig. 1E). These probably were produced by a predatory Octopus (Bromley 1993);

3. Subcircular holes ( 8 specimens, $1.5-2 \mathrm{~mm}$ in diameter) located on the cardinal commissure (Fig. $1 G)$. A slightly abraded area is noticeable around the hole and tangential to it. This area is also subcircular in shape and measures ca. $10 \mathrm{~mm}$ in diameter. Similar traces are produced by Capulus danieli from $\mathrm{S}$. Pacific. This capulid is parasitic in nature and inserts its proboscis through the hole to take food from the foodgathering tracts of its prey. It is remarkable that neither fossil nor living capulids showing similar trophic habits are known in the Mediterranean Sea, though a specimen (Fig. 1H) was found which has a hole in the commissure area and also a capulid attached in the central portion of its brachial valve. The position of the capulid is not the usual one, but it is possible that the gastropod shifted its position during the process of burial and diagenesis. This discovery strengthens the hypothesis that these traces are due to capulids. Similar traces, more subelliptical in shape, have been found on Terebratula scillae Seguenza (Lower Pleistocene, Calabria) (Taddei Ruggiero 1989, 1991).

Oichnus ovalis Bromley, 1993 (Fig. 1F)

The boreholes are oval in shape $(3$ specimens, ca. $0.5 \times 0.8 \mathrm{~mm}$ ) and are probably attributable to predation by Octopus sp.

Podichnus centrifugalis Bromley \& Surlyk, 1973 (Fig. 1I-J)

These trace fossils are clusters of pits produced by pedicles of brachiopods. They are nearly symmetri- 

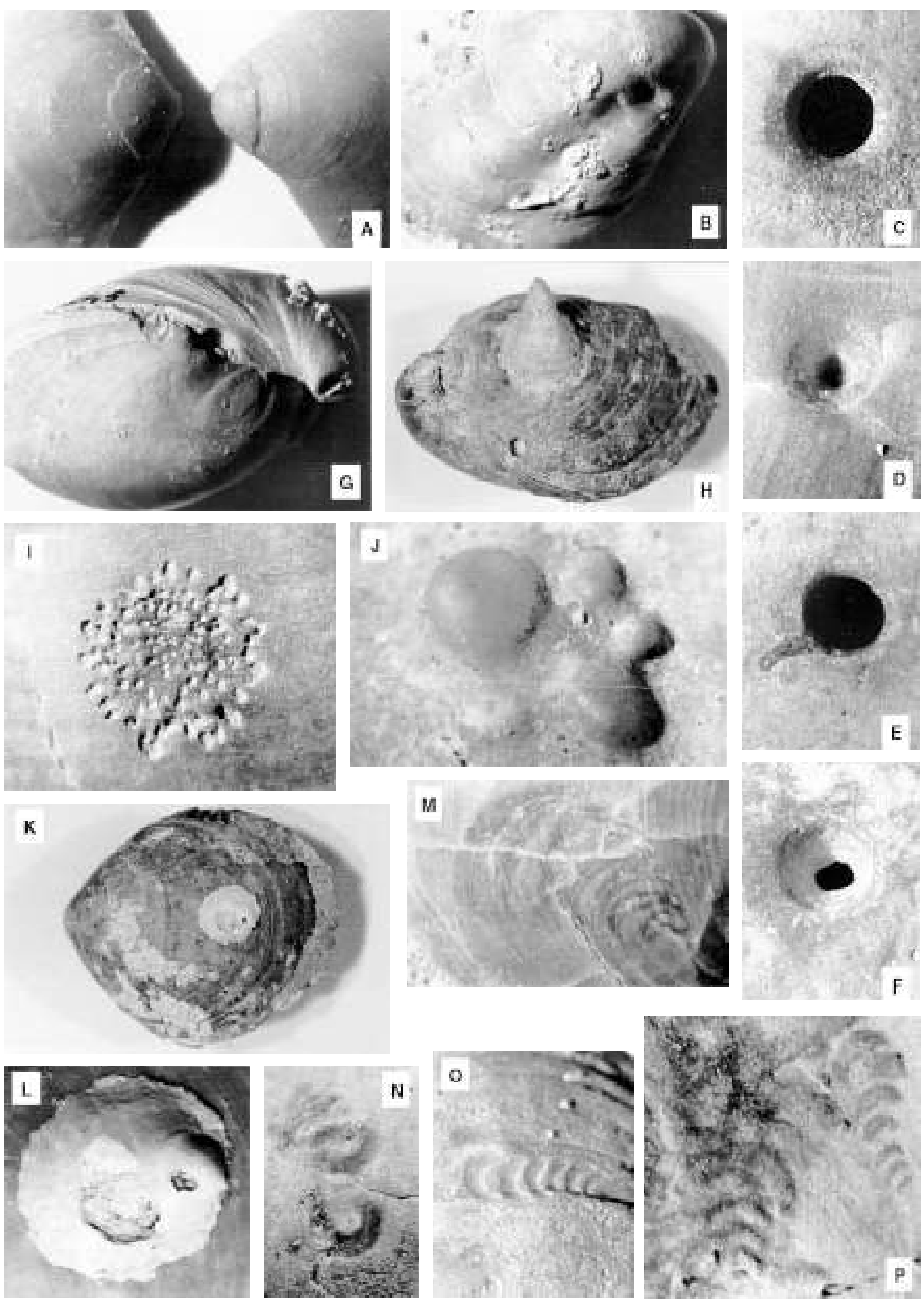
cal, the pits in the sub-central area being numerous, smaller in diameter and perpendicular to the shell surface; the others, more peripheral, being larger, oblique and penetrating deeper into the shell. The 19 clusters measure 1.5 to $3.3 \mathrm{~mm}$ in diameter.

The traces found on T. calabra are due to a pedicle provided with numerous papillae. On the basis of the gregarious way of life of many species of brachiopods and the relatively large size of the trace fossils, the scars may be considered to be due to fixation of other specimens belonging to the same species as the host animal.

\section{Entobia isp.}

Several trace fossils of this ichnogenus have been found, but only a few of them affected the shell during the life-span of the brachiopods.

Tubular cavities perhaps attributable to Polychaeta have been found on 4 specimens.

\section{Etching}

Centrichnus eccentricus Bromley \& Martinell, 1991 (Fig. 1M)

Traces produced by the cemented attachment of Anomiidae (Fig. 1K-L) (8 specimens, length 10 to 12 $\mathrm{mm})$.

Renichnus arcuatus Mayoral, 1987 (Fig. 1O-P)

Traces resulting from the attachment of vermetid gastropods ( 5 specimens, length 4 to $5 \mathrm{~mm}$ ).

\section{Unidentified}

In addition to the above, several unidentified traces have been found (Fig. 1N).

According to an ethological classification, the traces studied belong to (a) Praedichnia: traces of breakage and Oichnus ispp. and (b) Domichnia: Entobia, borings caused by Polychaeta and etchings of epibionta, including Podichnus, Centrichnus and Renichnus.

\section{Conclusions}

In a previous study of macro- and microfaunae associated with Terebratula calabra (Taddei Ruggiero 1996) it was suggested that these brachiopods lived on a muddy biodetritic substrate at a depth of 100 $120 \mathrm{~m}$, in a cold-temperate climate, during the Upper Pliocene: Globorotalia inflata Zone. The bioerosion trace fossils occurring in this population allow us to better specify some aspects of the way of life of Terebratula calabra and its relationships with the environment.

Trace fossils attributable to epibionta (Anomiidae, gastropods, brachiopods), occurring on both valves, indicate that $T$. calabra lived completely epibenthically on the mobile substrate. The distribution of Podichnus suggests that it was produced by T. calabra itself, living in clusters on one another, and the morphology of the trace fossil indicates that their pedicle was provided with numerous papillae.

Probably, predators of Terebratula were decapod crustaceans, gastropods and Octopus, but the percentage of shells in this population that show signs that they have been preyed upon is low.

Brachiopods usually repair damage by thickening the shells through secretion of additional material of their fibrous secondary layer (Fig. 1J). However, boring attacks by gastropods or Octopus leave the brachiopods with no chance of defence, and no evidence of survival is seen in these cases.

\section{Dansk sammendrag}

De vigtigste former for bioerosion i skaller af levende eksemplarer af Terebratula calabra fra Italiens Pliocæn kan grupperes som: overfladiske ætsninger, boringer og skalbrud. Sporslægter er Oichnus, Podichnus, Entobia, Centrichnus og Renichnus.

Fig. 1. Traces of bioerosion on Terebratula calabra Seguenza. A, Breakage along the shell edge of both valves. This breakage took place in an early growth stage and did not affect subsequently the normal growth of the shell, \#3519, $\times 2.8$; $\mathrm{B}$, Breakage affecting a small portion of the shell at an early stage of the growth, causing a deformation in the subsequent growth, \#1038, × 2.3; C-E, G-H, Oichnus simplex Bromley; C, hole penetrating through the shell, \#1051, $\times 8.6 ; \mathrm{D}$, incomplete hole, $\# 1033, \times 8.6$; E, hole with side gutter, \#1049, × 8.6; F, Oichnus ovalis Bromley, \#1070, $\times 8.6$; G, hole with subcircular abraded area, \#3545, $\times 2.6 ; \mathrm{H}$, hole in the commissure area and capulid on brachial valve, $\# 1036, \times 1.3$; I-J, Podichnus centrifugalis Bromley \& Surlyk, \#1033, × 13.8; I, outer surface; J, inner surface, the brachiopod has repaired the damage by thickening the shell; K-L, Anomiidae on pedicle valve of T. calabra, \#3758; K, $\times 1.3 ; \mathrm{L}, \times 4.3$; M, Centrichnus eccentricus Bromley \& Martinell, \#1047, × 3.8; N, unidentified trace fossil, \#1040, $\times$ 5; O-P, Renichnus arcuatus Mayoral, $\times 6$; O, \#3689; $\mathrm{P}, \# 1037$. Specimen numbers refer to the collections in the Department of Earth Sciences, University of Naples. 


\section{References}

Bromley, R. G. 1981: Concepts in ichnotaxonomy illustrated by small round holes in shells. Acta Geologica Hispanica $16,55-64$.

Bromley, R. G. 1993: Predation habits of octopus past and present and a new ichnospecies, Oichnus ovalis. Bulletin of the Geological Society of Denmark 40, 167-173.

Bromley, R. G. \& Martinell, J. 1991: Centrichnus, new ichnogenus for centrically patterned attachment scars on skeletal substrates. Bulletin of the Geological Society of Denmark 8, 243-252.

Bromley, R. G. \& Surlyk, F. 1973: Borings produced by brachiopod pedicles, fossil and recent. Lethaia 6, 349365.

Mayoral, E. 1987: Acción bioerosiva de Mollusca (Gastropoda, Bivalvia) en el Plioceno inferior de la Quenca del Bajo Guadalquivir. Revista Española de Paleontologia 2, 49-58.

Taddei Ruggiero, E. 1989: Evidenze di predazione e parassitismo su gusci di Brachiopodi. Atti 3. Simposio Ecologia e Paleoecologia delle Comunità Bentoniche, 615-631.

Taddei Ruggiero, E. 1991: A study of damage evidence in brachiopod shell. In: Mac Kinnon, D. I., Lee, D. E. \& Campbell, J. D. (eds) Brachiopods through time, 2nd International Brachiopod Congress, 203-210. Balkema, Rotterdam.

Taddei Ruggiero, E. 1996: Biostratigrafia e paleoecologia delle Calcareniti di Gravina nei dintorni di Cerignola (Brachiopodi e Foraminiferi). Memorie della Società Geologica Italiana 51, 197-207. 